\title{
Exploration of the Energy Efficiency of the Greater London Authority Building (GLA Building/City Hall)
}

\author{
*EMEKA EFE OSAJI; JOHN HUDSON; PAUL CHYNOWETH \\ Research Institute for the Built and Human Environment (BUHU), \\ University of Salford, $4^{\text {th }}$ Floor, Maxwell Building, M5 4WT, United Kingdom
}

\begin{abstract}
This research paper set out to explore the following research question: "what shape and form should a building be in order to achieve energy efficiency in the design and construction of the tall office building?" This involved the exploratory case study of a spheroid building, the Greater London Authority (GLA) building. The Greater London Authority building was acclaimed as being energy efficient, with claims of $75 \%$ reduction in its annual energy consumption compared to a high specification office building. This claim was explored to better understand the nature of the spheroid form in construction. @JASEM
\end{abstract}

"The question of what shape a building should be is one of the most fundamental issues that confront an architect." (Hawkes 1996, p. 36) The importance of this statement is predicated on two factors, one is the factor of energy efficiency and the other is the factor of cost efficiency. Factors one and two are identified as issues in two questions; "What shape should a building be to reduce heat losses?" (Martin and March 1972, p. 57) and "What shape should a building be to reduce its cost?" (Martin and March 1972, p. 67) Further, the importance of these two factors of energy efficiency and cost efficiency are highlighted in the following statements: Statement 1: "The Energy Review (PIU, 2002) highlights the need to improve energy efficiency in buildings and recommends action to deliver a phased transition to low energy commercial buildings through the development of the Building Regulations." (Wade et al 2003)

Statement 2: "Within the commercial sector, offices, together with warehouses and retail premises, are a significant contributor to energy use and carbon emissions. From these three sub-sectors, offices seem to offer the greatest potential for action to achieve significant savings: the range of technical solutions is not too large as the nature of energy service demands in offices is relatively homogenous...." (Wade, et al 2003) (Table 2)

Statement 3: "The rapid growth in energy consumption in offices over the last three decades reflects expansion in floor space, and increased heating, lighting, IT and air conditioning (A/C) loads in individual buildings." (Wade, et al 2003)

Statement 4: "One commonly cited reason for the lack of investment in energy efficiency in buildings is that energy represents a small percentage of total occupancy costs, and therefore it is given little attention. However, in offices, particularly air conditioned ones, energy and the maintenance of heating and cooling equipment comprises a significant proportion of service charges." (Wade, et al 2003)
Statement 5: "In 2000, A/C office buildings had an average annual service charge of $£ 53.82$ per $\mathrm{m}^{2}$, compared to $£ 37.24$ for non-A/C buildings (Jones Lang LaSalle, 2001) (refer to table 1). Thus, in A/C offices energy itself represents $16 \%$ of total service charges; by including maintenance of heating and $\mathrm{A} / \mathrm{C}$ systems this brings the proportion up to $35 \%$. These are significant proportions, and therefore one might expect that tenants would be interested in lowering energy consumptions in their premises." (Wade, et al 2003)

Table 1 Service charge in UK offices by component percentages in 2000

\begin{tabular}{lcc}
\hline & $\mathrm{A} / \mathrm{C}$ & Non $\mathrm{A} / \mathrm{C}$ \\
& $16 \%$ & $11 \%$ \\
Energy & $19 \%$ & $9 \%$ \\
Heating and A/C maintenance & & \\
Other & $65 \%$ & $80 \%$
\end{tabular}

Based on Jones Lang Lasalle (2001) (Table source: Wade, Pett and Ramsay 2003, p. 14)

\section{CASE STUDY: THE GREATER LONDON AUTHORITY BUILDING}

On the $23^{\text {rd }}$ of July 2002, the New City Hall, known as the Greater London Authority (GLA) building was officially opened by Her Majesty, the Queen and was heralded as a solution to the issue of environmental efficiency in tall office buildings. However, concerns have arisen regarding its claims of energy efficiency. The design and construction of the Greater London Authority building led to the emergence of arguments relating to the actual and perceived problems, as well as benefits associated with the use of the spheroid form in attempting to achieve environmental efficiency in tall office buildings.

GLA Building: Height $=45 \mathrm{~m}$, Floors above ground level $=10$, Gross floor area $\approx$

$185,000 \mathrm{sq} \mathrm{ft} / 18,000 \mathrm{sq} \mathrm{m}$, Net letable floor area $\approx$ $130,000 \mathrm{sq} \mathrm{ft} / 12,000 \mathrm{sq} \mathrm{m}$,

Steelwork (structural frame) $=2100$ tons, Angle of glass front inclination $=31^{0}$, 
Diameter of circular glass façade $=45 \mathrm{~m}$, Energy use $=$ less than half levels in the

Department of the Environment, Transport and the Regions (DETR) good practice office guide.

According to (Powell, 2002, p. 1), "for Ken Shuttleworth of Foster and Partners, 'the starting point of the project was to reduce the energy load of the building by 75 percent.' The headquarters of the Greater London Authority, to be known as City Hall, is nothing if not environmentally responsible, a practical demonstration, the architect claims, of the potential of sustainable design in a world city where, so far, that concept has made a negligible impact."

Table 2 Energy consumption and $\mathrm{CO}_{2}$ emissions in UK commercial offices

\begin{tabular}{|c|c|c|c|c|c|c|c|c|c|c|c|}
\hline & 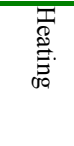 & 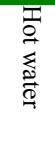 & 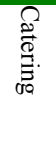 & 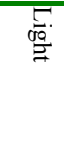 & $\begin{array}{l}\Omega \\
\stackrel{8}{\Xi} \\
\stackrel{\Xi}{\Xi}\end{array}$ & 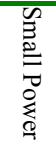 & $\exists$ & $\underset{9}{\stackrel{9}{9}}$ & $\begin{array}{l}\overrightarrow{0} \\
\text { D } \\
\mathscr{D} \\
\mathscr{\infty}\end{array}$ & 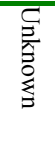 & 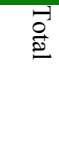 \\
\hline Fossil fuels (PJ) & 46 & 5 & 3 & - & - & - & - & - & - & - & 54 \\
\hline \multicolumn{12}{|l|}{ Electricity (PJ) } \\
\hline & 5 & 0 & 3 & 16 & 11 & 2 & 12 & 2 & 3 & 0.3 & 56 \\
\hline \multicolumn{12}{|l|}{$\mathrm{CO}_{2}(\mathrm{kT})$} \\
\hline & 3680 & 469 & 370 & 2238 & 1319 & 250 & 1031 & 184 & 7 & 121 & 9669 \\
\hline
\end{tabular}

(Table source: Wade, Pett and Ramsay 2003,p. 4)

Greater London Authority (2005, p. 1) states: "Energy consumptions for [the Greater London Authority Building's] environmental systems are less than half levels in DETR good practice office guide. (table 3) The radical shape of the building minimises the surface area (approximately 25 percent less than equivalent rectangular building), is self shading and the high performance façade ensures excellent energy efficiency."

Mean of good practice levels $=($ Type $1+$ Type $2+$ Type $3+$ Type 4$) / 4$.equation 1

Mean of good practice levels $=(112+133+225+$ 348) $\mathrm{kWh} / \mathrm{m}^{2} \div 4$ equation 2

Mean of good practice levels $=818 \mathrm{kWh} / \mathrm{m}^{2} \div 4$ equation 3

Table 3 Typical and Good Practice Energy Consumption in Offices in the UK

\begin{tabular}{|c|c|c|c|c|c|c|c|c|}
\hline & \multicolumn{6}{|c|}{$\mathrm{kWh} / \mathrm{m}^{2}$ of treated floor area } & \multirow{2}{*}{\multicolumn{2}{|c|}{ Type 4}} \\
\hline & Type & & Typ & & Type & & & \\
\hline & $\begin{array}{l}\text { Good } \\
\text { practice }\end{array}$ & Typical & $\begin{array}{l}\text { Good } \\
\text { practice }\end{array}$ & Typical & $\begin{array}{l}\text { Good } \\
\text { practice }\end{array}$ & Typical & $\begin{array}{l}\text { Good } \\
\text { practice }\end{array}$ & Typical \\
\hline $\begin{array}{l}\text { Heating \& hot } \\
\text { water }\end{array}$ & 79 & 151 & 79 & 151 & 97 & 178 & 107 & 201 \\
\hline Cooling & 0 & 0 & 1 & 2 & 14 & 31 & 21 & 41 \\
\hline $\begin{array}{l}\text { Fans, pumps \& } \\
\text { controls }\end{array}$ & 2 & 6 & 4 & 8 & 30 & 60 & 36 & 67 \\
\hline Humidification & 0 & 0 & 0 & 0 & 8 & 18 & 12 & 23 \\
\hline Lighting & 14 & 23 & 22 & 38 & 27 & 54 & 29 & 60 \\
\hline Office equipment & 12 & 18 & 20 & 27 & 23 & 31 & 23 & 32 \\
\hline Catering & 2 & 3 & 3 & 5 & 5 & 6 & 20 & 24 \\
\hline Other electricity & 3 & 4 & 4 & 5 & 7 & 8 & 13 & 15 \\
\hline Computer room & 0 & 0 & 0 & 0 & 14 & 18 & 87 & 105 \\
\hline
\end{tabular}


It can be deduced from the results of equations 1 to 8 that the Greater London Authority building's energy consumption level is less than half mean levels in DETR good practice office guide, is less than individual DETR good practice office guide total levels for Type 1 (Naturally ventilated cellular) and Type 2 (Naturally ventilated open- plan), and is less than half levels in DETR good practice office guide for Type 3 (A/C, standard) and Type 4 (A/C, prestige) (refer to table 3 ). The Greater London Authority building's low energy consumption can be attributed not only to its spheroid form but also to other innovative solutions, such as:

- "For cooling the building, naturally chilled borehole water is brought up $125 \mathrm{~m}$ from the aquifer below the London clay. The boreholes use less energy than conventional chillers and cooling towers and are an economical alternative to install and maintain." (Arup, 2002)

- "The diagrid structure supports the north façade of the GLA building and is in fact the largest radiator in London. The majority of the horizontal steel elements, measuring a staggering $300 \mathrm{~mm}$ in diameter each, have hot water coursing through them to act as a discreet heater for the atrium space that doesn't require extra fittings or pipe work installation." (Arup 2002)

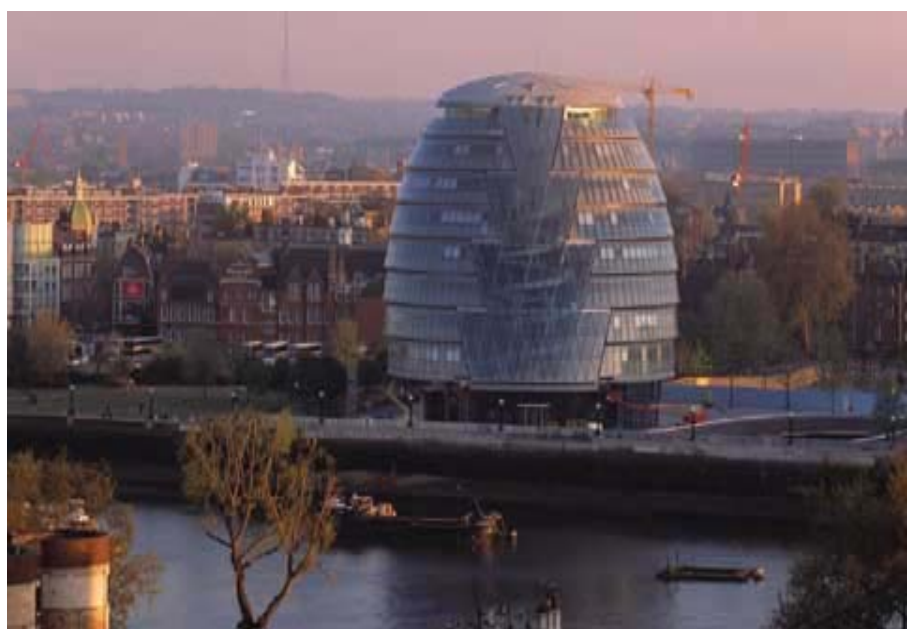

Fig. 1 City Hall at dawn (Image source: (C) Government Office for London, 2004)

- "Detailed analysis by Arup resulted in the design of a very efficient façade. It is made up of insulated panels that reduce the solar gain, as well as heat loss to half that of a normal office building." (Arup 2002, p. 1)

- "The façade also incorporates flexible, locally controlled natural ventilation. When the natural air vents are opened, 'smart' air conditioning and heating systems deactivate themselves in the adjacent area to prevent energy waste." (Arup 2002)

Greater London Authority, 2002, p. 3), "the BREEAM (Building Research Environmental Assessment Method) is a very useful tool in which to objectively review the design of buildings from an environmental perspective."

Further, Greater London Authority (2002,) states “a BREEAM Design and Procurement Assessment (under BREEAM 98 for Offices) has been carried out for the Greater London Authority. The building has been awarded an EPI of 10 out of 10 (Environmental Performance Indicator) and under the BREEAM Design and Procurement Assessment the building has been awarded an excellent rating, having scored $76 \%$."

Greater London Authority (2002, p. 3) also states "whilst other buildings, such as Wessex Water have been awarded an excellent rating, it is interesting to note that the BRE's own Environmental Building only achieved a Very Good."

Conclusion: This research paper carried out an exploratory case study of a spheroid building, the Greater London Authority (GLA) building. The Greater London Authority building was acclaimed as being energy efficient, with claims of $75 \%$ reduction in its annual energy consumption compared to a high specification office building. The GLA building's energy efficiency claims were explored in comparison to that of other office types and the summary of its BREEAM Assessment was also examined. The GLA building's energy efficiency claim was explored to better understand the nature of the spheroid form in construction

\section{REFERENCES}


Arup, (2005) GLA - the Queen launches a flagship for a greener city, Arup, Available at: <URL: http://www.arup.com/newsitem.cfm?pageid $=966$ $>$ [accessed 16 February 2005], p. 1

DETR, (2000b) Energy Efficiency Best Practice Programme Energy Consumption Guide 19 Energy use in offices London: Department of the Environment, Transport and the Regions 2000

Greater London Authority, (2005) City Hall - a 'green' building, London, Available at: $<\mathrm{URL}$ : http://www.london.gov.uk/gla/city_hall/city_hall _green.jsp $>$ [accessed 16 February 2005], 2005, p. 1

Greater London Authority, (2002) Environmental Assessment of City Hall (Report Number: 7), London: Greater London Authority 2002

Hawkes, D., (1996) The Environmental Tradition London: E \& FN Spon 1996, p. 36
Jones Lang LaSalle, (2001) Service Charge Analysis for offices, Office Service Charge Analysis Research (OSCAR), Available at: <URL: www.joneslanglasalle.co.uk>, 2001

O'Meagher, T.; Ferguson, A., (2005) Fire Engineering at the GLA Building, ArupFire, Available

at: <URL:http://www.umist.ac.uk/departments/civil/ research/ structures/strucfire/ CaseStudy/steelComposite/default.htm> [accessed 29 October 2005], p. 1

Powell, K., (2002) London Pride Structure, London: Architects' Journal 2002

Wade, J.; Pett, J.; Ramsay, L., (2003) Energy efficiencies in offices: assessing the situation, London: Association for the Conservation of Energy 2003 